\title{
Evaluation of User Experience on Digital Learning Platform Website Using System Usability Scale (Case Study: Pijar Mahir)
}

\author{
Joshua Laurence, \\ Emil R. Kaburuan \\ Jakarta, Indonesia
}

Article History: Received: 10 November 2020; Revised 12 January 2021; Accepted: 27 January 2021; Published online: 5 April 2021

\begin{abstract}
User experience is one of the most important factors of an application. Pijar Mahir is a digital learning platform to increase job seekers skill. This research evaluates usability of pijarmahir's website using system usability scale (SUS). SUS consists of ten statements as an evaluation instrument. Based on the results of SUS evaluation of the 101 respondents, Pijar Mahir's website has an average SUS score of 72,67. Based on the result, 72,67 is in an "acceptable" category.
\end{abstract}

Keywords: E-Learning, system usability scale, user experience

\section{Introduction}

Unemployment is a problem that is often experienced by developing countries, including Indonesia. Unemployment is the main concern that every government in the world wants to solve, especially Indonesia. Unemployment is a state where someone who is in the workforce, who wants to find / getting a job but not getting a job (Sukirno, 1994). Unemployment has various adverse effects for the country, such as: a decrease in per capita income, a deep social gap of society, the swelling of social costs that must be borne by the government, instability of social and political conditions, and increasing the country's debt (Hasanah, 2016). Various efforts have been made by the Indonesian government to solve existing unemployment and employment problems. In Indonesia itself, the unemployment rate has started to decrease, although not yet reduced significantly, but the government continues to try to keep the pace of unemployment rates to decrease in Indonesia.

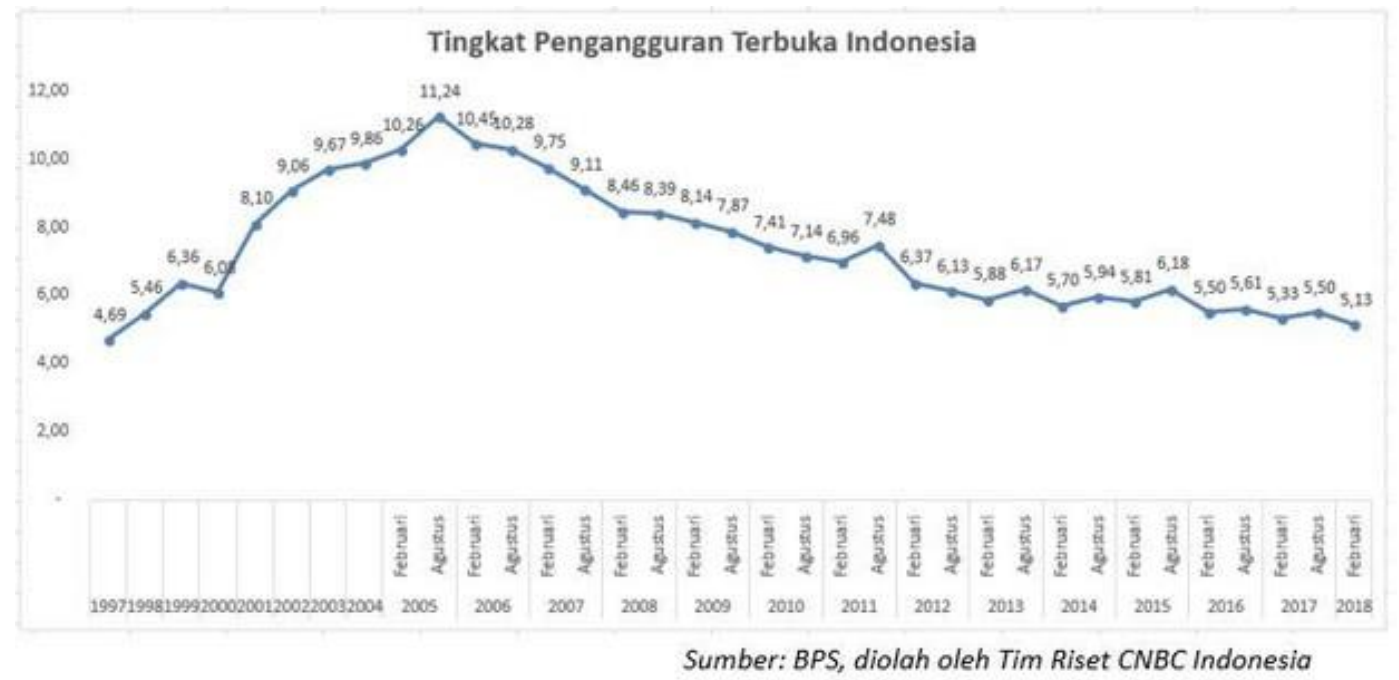

Fig. 1.1. Unemployment rate in Indonesia (CNBC Indonesia, 2018)

It can be seen from fig. 1.1, the unemployment rate of Indonesia has steadily decrease in the past few years. The decrease from the unemployment rate cannot be separated from the work of the Indonesian government. 
Recently, the government of Indonesia has focused on reducing the unemployment rate through increasing the competence of workers in the country. The government has made a program in developing work competences and entrepreneurship of Indonesian, through Kartu Prakerja. Kartu Prakerja is a program released by the government for develop the competences of job seekers and everybody that has affected by workers termination of employment rights.

Kartu Prakerja distributes their module online, so that everyone can access the contents provided easier. Kartu Prakerja held several partnership with digital learning platform such as: Pijar Mahir, Ruang Guru, Skill Academy, etc. This program is a form of partnership between the government and the private sector in developing better human resources. Pijar Mahir is a digital learning platform and certification that provides easy access for community in increasing their expertise and competence with current and future needs of the Industry.

One of the most important things that must be considered by Pijar Mahir is user experience when using / interacting with a product, where it is subjective because it comes from perceptions and thoughts from each individual, based on how they feel. User Experience (UX) is the response and perception of each user that is caused by the use of a product or service. UX represents how user satisfaction and pleasure while using, see, and feel a product / service (International Organization for Standardization, 2010). One of the goals of creating a website is to provide good experience to its users, by presenting good informations effectively and easy to understand. To measure the level of ease with which users interaction with Pijar Mahir website, can be measured by the System Usability Scale (SUS). System Usability Scale is a questionnaire used to measure perception of usability. The purpose of this research is to evaluates user experience of Pijar Mahir's website.

\section{Methodology}

\subsection{Research Object}

Object for this evaluation is Pijar Mahir's website. Pijar Mahir's website can be accessed through "pijarmahir.id". opening up the website for the first time will show the website's home screen. In the home screen, as shown on fig. 2.1, there are banner, search field, course lists, wishlists, chart, accound and notification. In this website people can search through courses that they want to learn and buy it. All the proccess from searching courses to payment are accesed online.

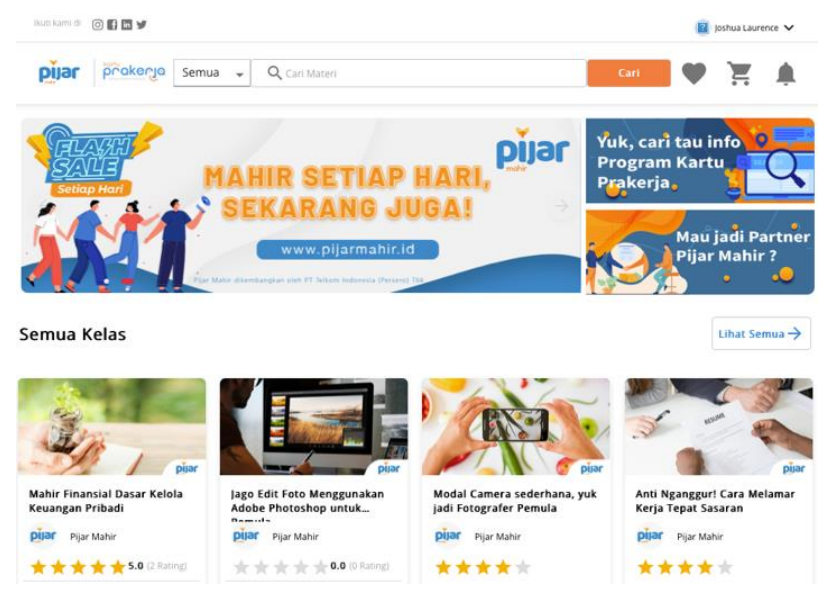

Fig. 2.1. Website's homepage

\subsection{Sample and Population}

Population is a generalization of one area that has been determined by researchers to choose the samples which consist of objects / subjects which has certain characteristics and qualities (Sugiyono, 2018). Because the purpose of this website is to increasing competenses for job seekers and unemployment, then the populations for this research are residents of DKI Jakarta whose registered as job seekers. As shown on the fig. 2.2 total population of this research is 30.338 . 


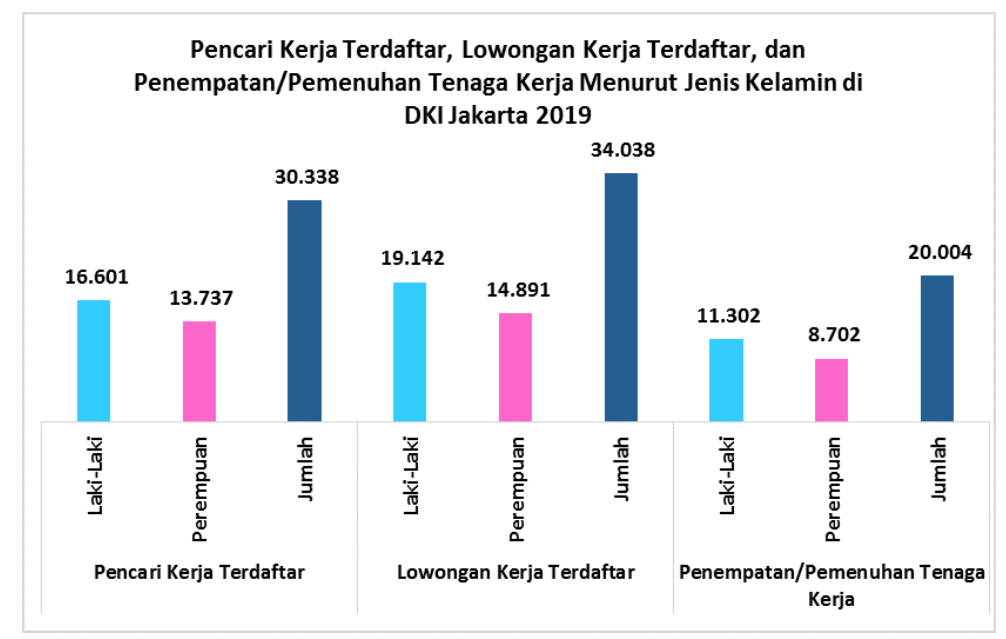

Fig. 2.2. Job seekers in DKI Jakarta

And to determine the sample required in this research, the author will use Slovin formula. Slovin formula is a formula for calculating the minimum sample size if the behavior of the exact population is unknown. The slovin formula is commonly used in survey research where usually the number of samples is very large, so need a formula to get a small sample but also can represent the entire population. The sample for this research can be calculated as:

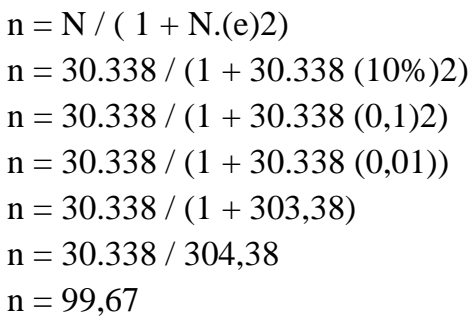

where $\mathrm{n}$ is sample required, $\mathrm{N}$ is population, and e is error margin. The population for this research is 30.338 , and for the error margin is $10 \%$. So the sample required for this research is 99,67 and will be rounded to 100 person.

\section{Methodology}

Based on the fig. 2.2, this research will start from define the respondent scenario, what will they do regarding to evalute Pijar Mahir's website. Define the method to know how much the respondents needed and how to collect the data. After that, analyze the data gained from respondent. Last, researcher will give recomendation according to respondent's insights.

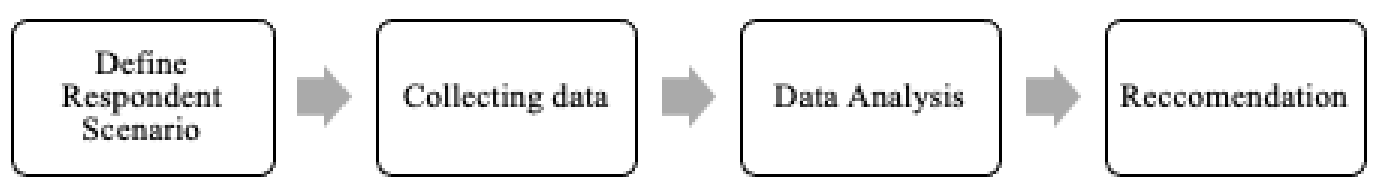

Fig. 2.2. Stages of research

This research uses qualitative method to gain deeper insight in what user feels about the website. The evaluation methodology for this research is system usability scale. System usability scale is a questionnaire to measure the perceived usefulness created by John Brooke in 1986. System Usability Scale (SUS) contains 10 questions where participants are given a choice of scale 1-5 to answer based on how much they agree with each of the statements given, against the products or features that will be tested. A value of 1 means strongly disagree 
and 5 means strongly agree with the statement given (Alathas, 2018). These are the list of the system usability scale statetements:

1. I think that I would like to use this website frequently.

2. I found the website unnecessarily complex.

3. I thought the website was easy to use.

4. I think that I would need the support of a technical person to be able to use this website.

5. I found the various functions in this website were well integrated.

6. I thought there was too much inconsistency in this website.

7. I would imagine that most people would learn to use this website very quickly.

8. I found the website very cumbersome to use.

9. I felt very confident using the website.

10. I needed to learn a lot of things before I could get going with this website.

System usability scale has its own way to calculate, these are the rules on how to calculate the system usability scale results:

1. For every odd numbered question, the questionnaire score will be reduced by $1(\mathrm{X}-1)$.

2. For every even numbered question, the questionnaire score will be reduced from 5 (5-X).

3. Sum all the even and odd numbered question.

4. Multiply the sum result with 2,5.

5. Calculate the average of SUS score based on the multiply result.

For the last proccess of evaluating using system usability scale is to determine the category of average SUS score. After researcher get the average SUS score calculated, then determine the score to know the system is in an acceptable category or not. To find out the SUS value that falls into the acceptable category, Aaron Bangor, Philip T. Kortum, and James T. Miller suggested that the system is said to be feasible, if it has an SUS score of at least 70. Then for the system can be categorized as good, has a SUS score of the 70s to 80s. And for the system which is in the very good category, has an SUS score above 90 . And for the system those with a SUS score below 70 can be considered as a system that must be put under supervision for further development (Bangor et al., 2008).

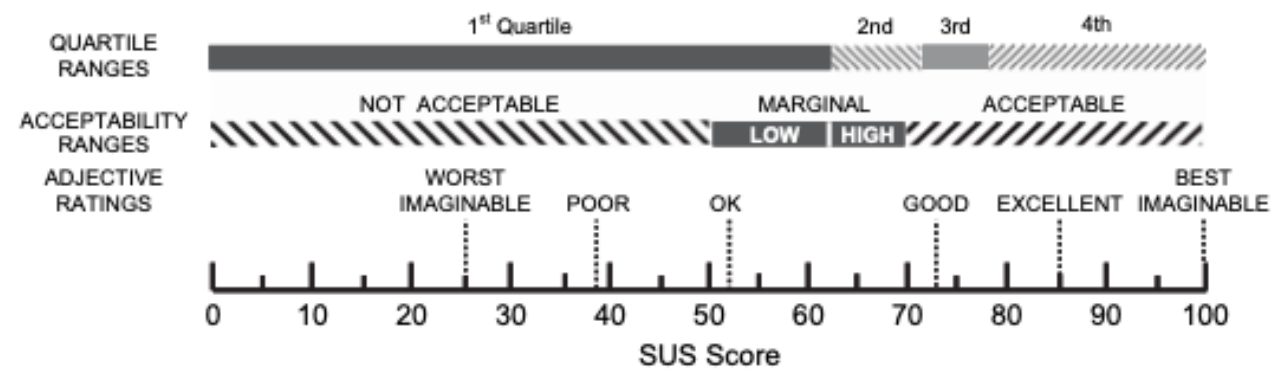

Fig 2.3. SUS score category

\section{Results and Finding \\ 4.1 Respondent's Profile}

1. Respondent's gender 
Apakah Jenis kelamin anda?

101 responses

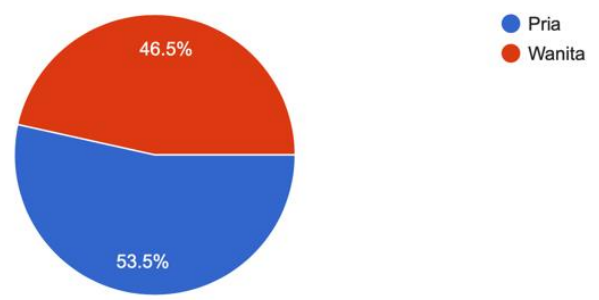

Fig 3.1. Respondent's gender

Based on the system usability scale questionnaire that has been done, the respondents profile based on gender from a total of 101 respondents were 54 male and 47 woman.

2. Respondent's age

Berapakah usia anda?

101 responses

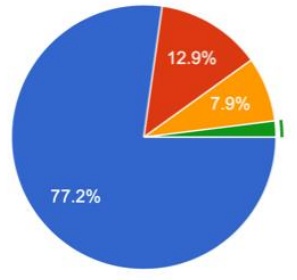

$25-35$ tahun

35 - 50 tahun

$>50$ tahun

Fig. 3.2. Respondent's age

Based on the system usability scale questionnaire that has been done, the respondents profile based on age from a total of 101 respondents were, 78 respondents are 18-25 years old, 13 respondents are 25-35 years old, 8 respondents are 35-50 years old, and 2 respondents are over 50 years.

\subsection{Questionnaire Score from Each Number}

The system usability scale questionnaire consists of 10 questions on a scale of 1-5. Where the numbers represent whether the respondent agrees or not based on the statement given. The smaller the value means the respondent strongly disagrees and the larger value, meaning that the respondent strongly agrees with the statement given. The following are the results of the questionnaire for the system usability scale question:

1. I think that I would like to use this website frequently. 


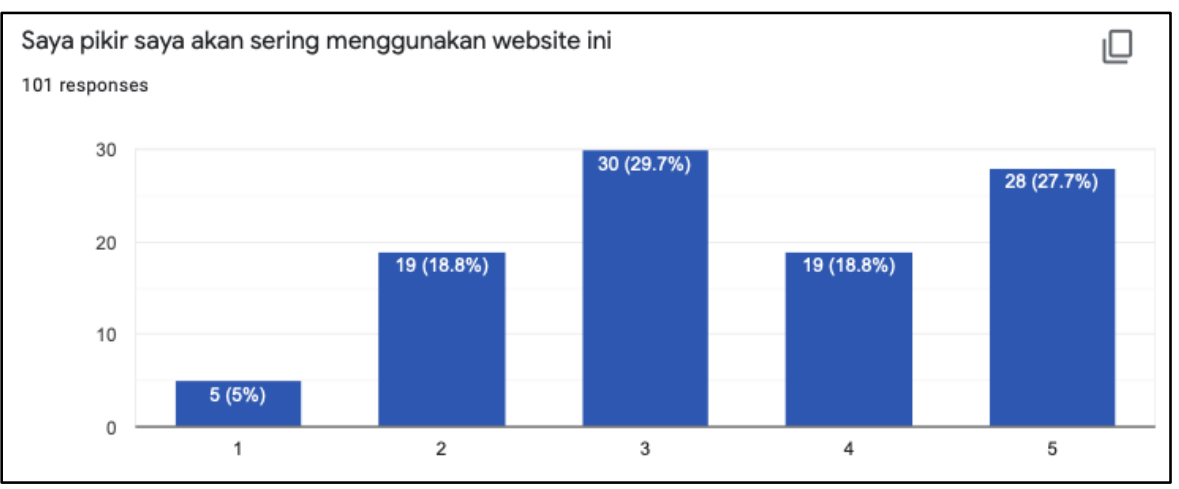

Fig 3.3. Questionnaire results from number 1

Following are the respondents' answers to question number 1 . From a total of 101 respondents, a total of 5 respondents chose 1, 19 respondents chose 2, 30 respondents chose 3, 19 respondents chose 4 , and 28 respondents chose 5 .

2. I found the website unnecessarily complex.

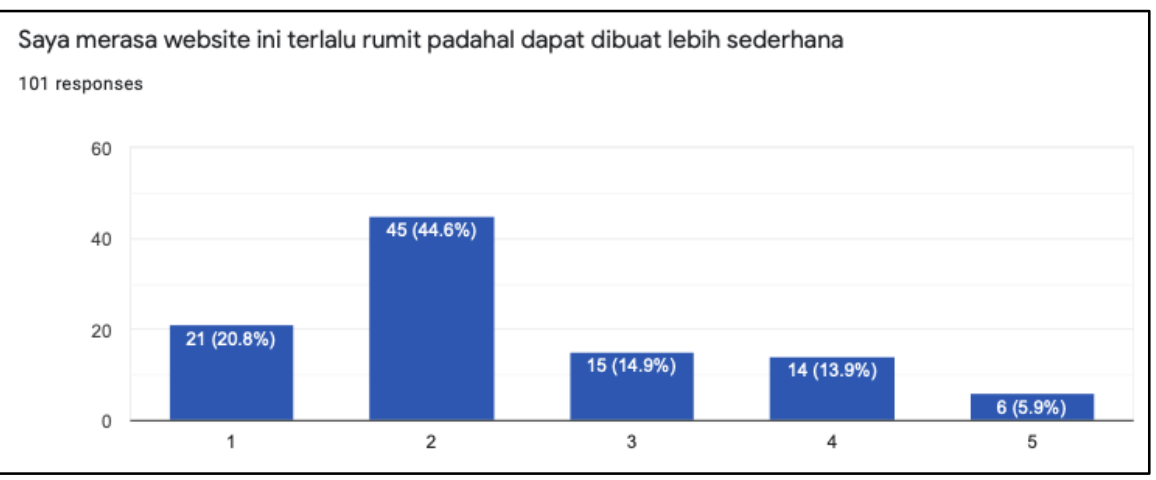

Fig 3.4. Questionnaire results from number 2

Following are the respondents' answers to question number 2 from a total of 101 respondents. A total of 21 respondents chose 1, 45 respondents chose 2, 15 respondents chose 3,14 respondents chose 4 , and 6 respondents chose 5 .

3. I thought the website was easy to use.

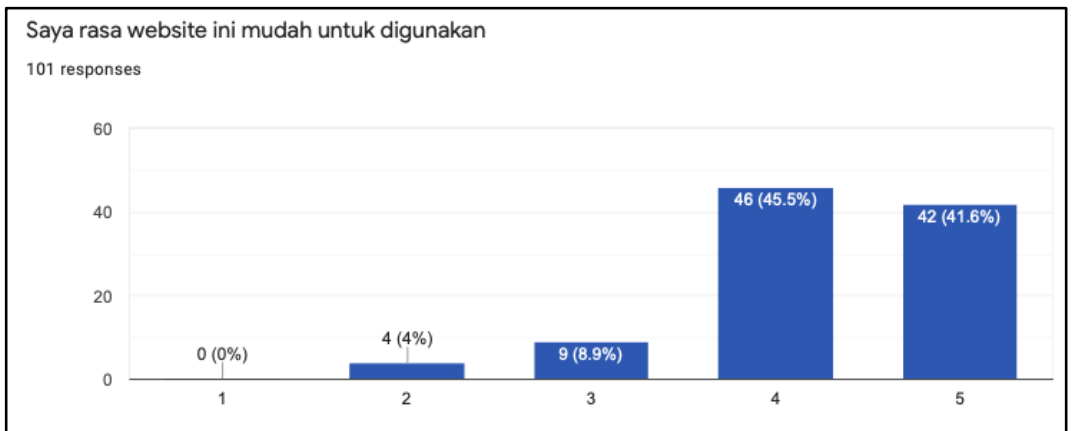

Fig 3.5. Questionnaire results from number 3 
Following are the respondents' answers to question number 3. From a total of 101 respondents, a number of 0 respondent chose 1, 4 respondents chose 2, 9 respondents chose 3, 46 respondents chose 4 , and 42 respondents chose 5 .

4. I think that I would need the support of a technical person to be able to use this website.

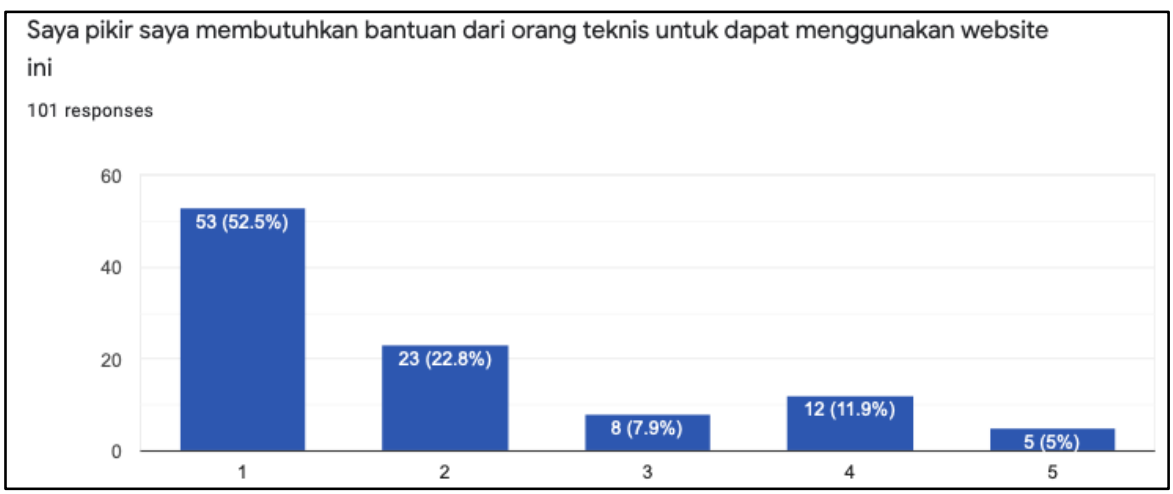

Fig 3.6. Questionnaire results from number 4

Following are the respondents' answers to question number 4 from a total of 101 respondents. A total of 53 respondents chose 1, 23 respondents chose 2, 8 respondents chose 3, 12 respondents chose 4 , and 5 respondents chose 5 .

5. I found the various functions in this website were well integrated.

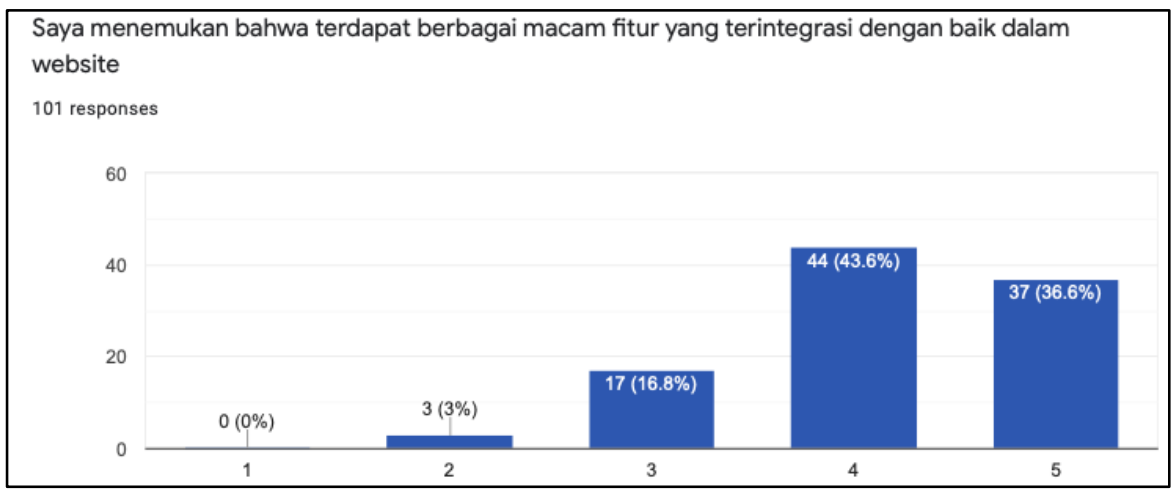

Fig 3.7. Questionnaire results from number 5

Following are the respondents' answers to question number 5 from a total of 101 respondents. A number of 0 respondents chose 1, 3 respondents chose 2, 17 respondents chose 3, 44 respondents chose 4 , and 37 respondents chose 5 .

6. I thought there was too much inconsistency in this website. 


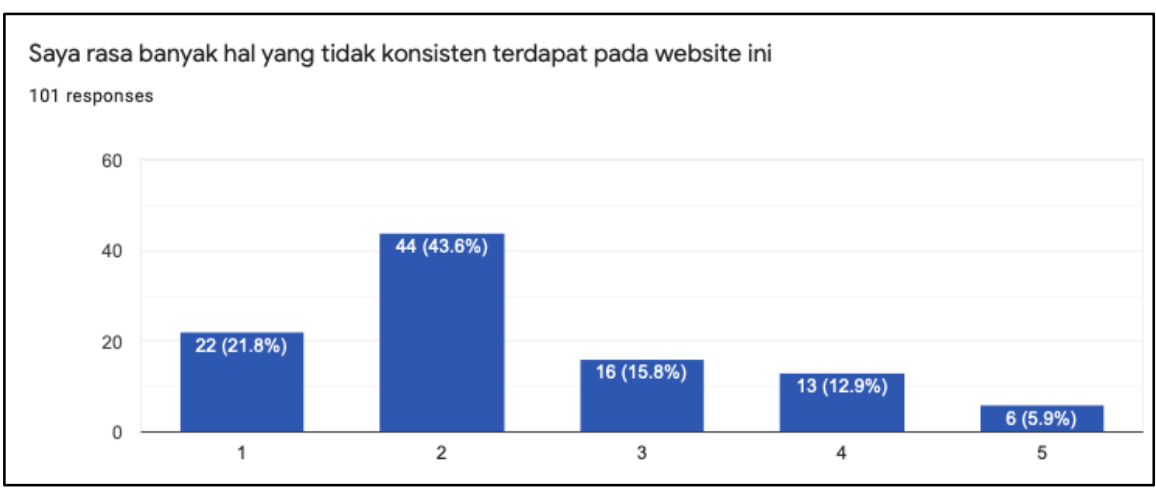

Fig 3.8. Questionnaire results from number 6

Following are the respondents' answers to question number 6 from a total of 101 respondents. A total of 22 respondents chose 1, 44 respondents chose 2, and 16 respondents chose 3,13 respondents chose 4 , and 6 respondents chose 5 .

7. I would imagine that most people would learn to use this website very quickly.

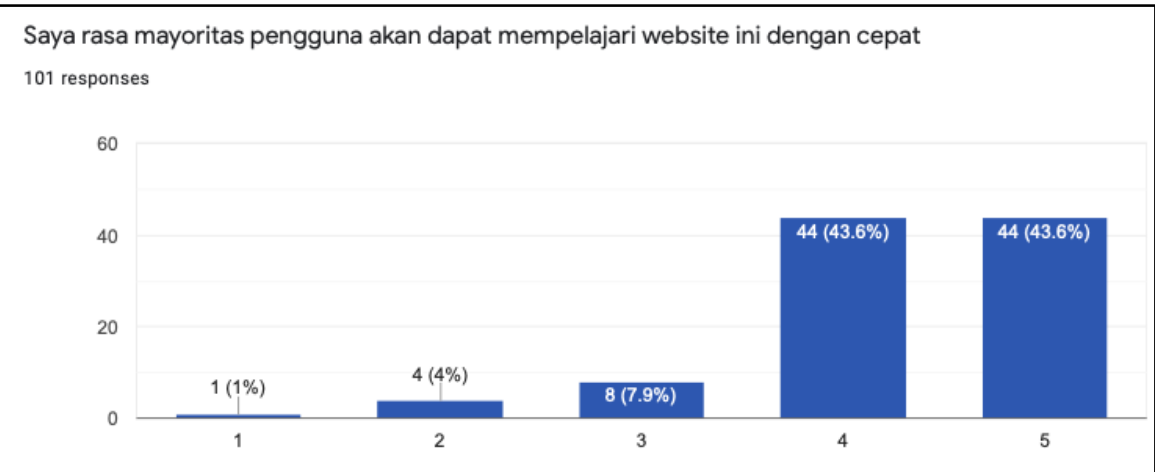

Fig 3.9. Questionnaire results from number 7

Following are the respondents' answers to question number 7 from a total of 101 respondents. A number of 1 respondent chose 1, 4 respondents chose 2, 8 respondents chose 3, 44 respondents chose 4 , and 44 respondents chose 5 .

8. I found the website very cumbersome to use.

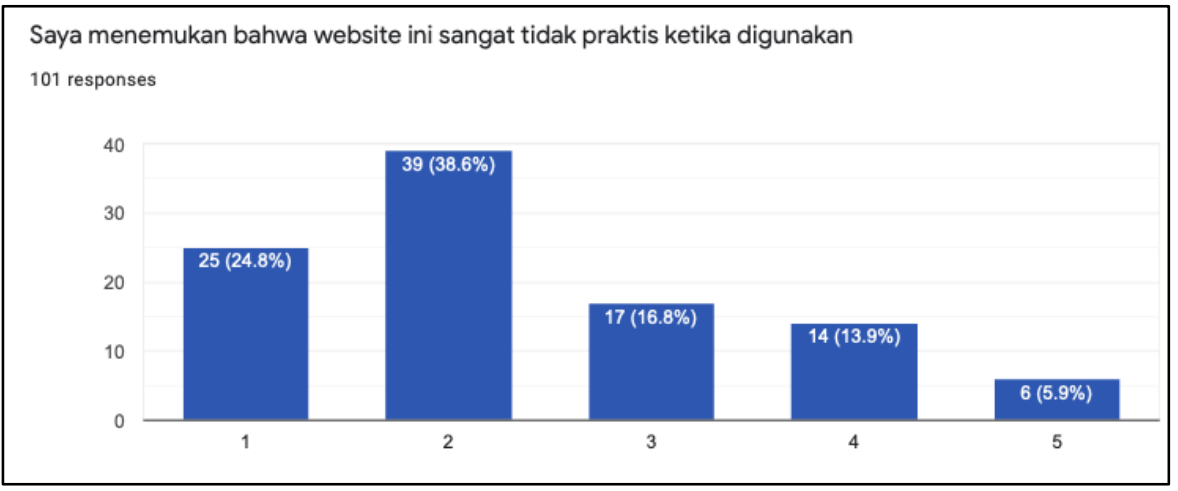

Fig 3.10. Questionnaire results from number 8 
Following are the respondents' answers to question number 8 from a total of 101 respondents. A total of 25 respondents chose 1, 39 respondents chose 2, 17 respondents chose 3, 14 respondents chose 4 , and 6 respondents chose 5 .

9. I felt very confident using the website.

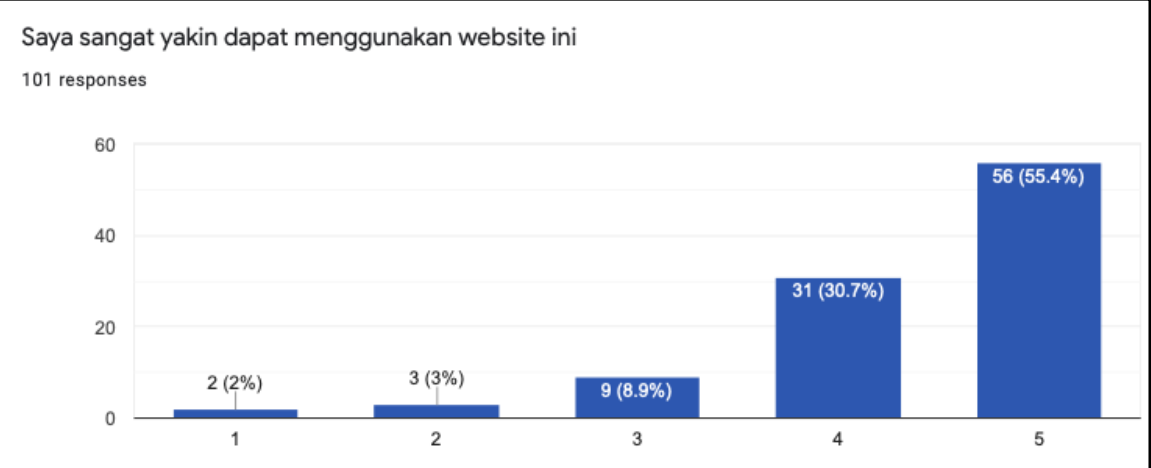

Fig 3.11. Questionnaire results from number 9

Following are the respondents' answers to question number 9 from a total of 101 respondents. A total of 2 respondents chose 1, 3 respondents chose 2, 9 respondents chose 3, 31 respondents chose 4 , and 56 respondents chose 5 .

10. I needed to learn a lot of things before I could get going with this website.

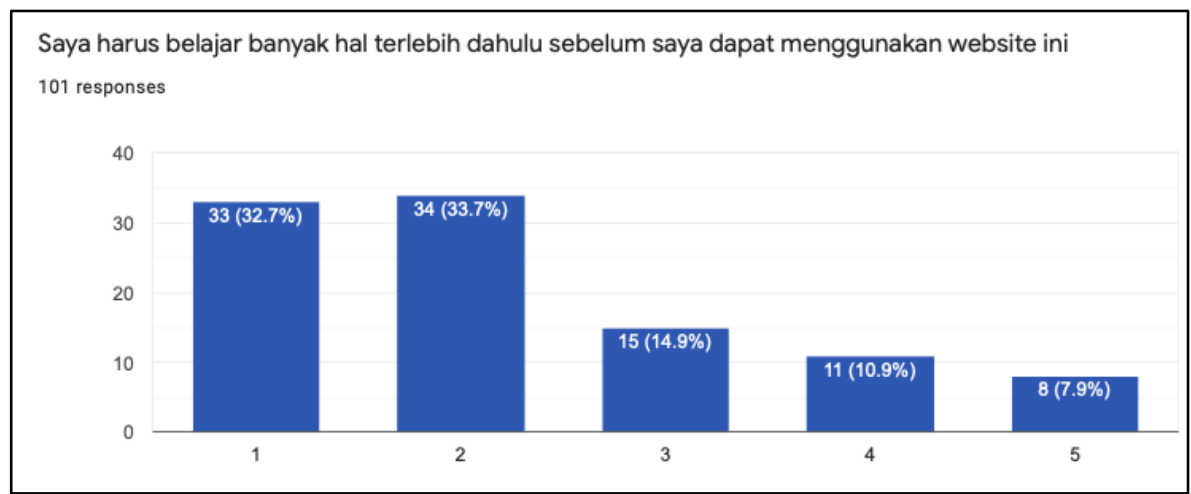

Fig 3.12. Questionnaire results from number 10

Following are the respondents' answers to question number 10 from a total of 101 respondents. A total of 33 respondents chose 1, 34 respondents chose 2, 15 respondents chose 3,11 respondents chose 4 , and 8 respondents chose 5 .

\subsection{SUS Score}

To perform calculations on the system usability scale, it is necessary to see the results of the questionnaire from each respondent. Each respondent filled out a questionnaire totaling 10 numbers on a scale of 1-5. The following is the result of the recapitulation SUS questionnaire based on the answers of each respondent: 
Table 3.1. SUS Score

\begin{tabular}{|c|c|c|c|c|c|c|c|c|c|c|}
\hline \multirow[t]{2}{*}{ Respondent } & \multicolumn{10}{|c|}{ Score from each questions } \\
\hline & Q1 & Q2 & Q3 & $\mathrm{Q} 4$ & Q5 & Q6 & Q7 & $\mathrm{Q} 8$ & Q9 & Q10 \\
\hline R1 & 4 & 4 & 4 & 4 & 4 & 4 & 3 & 4 & 3 & 4 \\
\hline $\mathbf{R 2}$ & 2 & 5 & 3 & 2 & 3 & 4 & 2 & 3 & 4 & 2 \\
\hline $\mathbf{R 3}$ & 2 & 4 & 5 & 1 & 4 & 2 & 5 & 1 & 5 & 1 \\
\hline R4 & 5 & 3 & 3 & 1 & 2 & 4 & 2 & 4 & 5 & 2 \\
\hline R5 & 4 & 4 & 4 & 4 & 4 & 4 & 4 & 4 & 4 & 4 \\
\hline R6 & 5 & 4 & 4 & 4 & 4 & 4 & 4 & 4 & 4 & 4 \\
\hline R7 & 5 & 4 & 4 & 4 & 4 & 4 & 5 & 4 & 4 & 4 \\
\hline R8 & 3 & 2 & 4 & 2 & 3 & 2 & 4 & 2 & 4 & 2 \\
\hline R9 & 5 & 4 & 4 & 1 & 4 & 2 & 4 & 4 & 5 & 2 \\
\hline R10 & 5 & 5 & 5 & 5 & 5 & 5 & 5 & 5 & 5 & 5 \\
\hline R11 & 4 & 3 & 4 & 3 & 4 & 3 & 4 & 3 & 4 & 3 \\
\hline$\ldots$ & $\ldots$ & $\ldots$ & $\ldots$ & $\ldots$ & $\ldots$ & $\ldots$ & $\ldots$ & $\ldots$ & $\ldots$ & $\ldots$ \\
\hline R101 & 4 & 2 & 4 & 1 & 5 & 1 & 4 & 1 & 5 & 1 \\
\hline
\end{tabular}

\subsection{Interpreting Scores}

To get the final value of system usability scale, several calculations are needed. The SUS value of odd questions minus $1(\mathrm{X}-1)$ and for the SUS scores of even questions, the questionnaire scores were reduced the value by $5(5-\mathrm{X})$. The rules applied to every respondent, so in order to get the final value from SUS, required calculations from all of the respondents that followed this research. The following is a table of the end results of SUS calculation.

Table 3.2. Average SUS Score

\begin{tabular}{lllllllllllll}
\hline Respondents & Q1 & Q2 & Q3 & Q4 & Q5 & Q6 & Q7 & Q8 & Q9 & Q10 & $\begin{array}{l}\text { Total } \\
\text { Score }\end{array}$ & $\begin{array}{l}\text { Score } \\
\mathbf{x}, 5\end{array}$ \\
\hline R1 & 3 & 1 & 3 & 1 & 3 & 1 & 2 & 1 & 2 & 1 & 18 & 45 \\
\hline R2 & 1 & 0 & 2 & 3 & 2 & 1 & 1 & 2 & 3 & 3 & 18 & 45 \\
\hline R3 & 1 & 1 & 4 & 4 & 3 & 3 & 4 & 4 & 4 & 4 & 32 & 80 \\
\hline R4 & 4 & 2 & 2 & 4 & 1 & 1 & 1 & 1 & 4 & 3 & 23 & 57.5 \\
\hline R5 & 3 & 1 & 3 & 1 & 3 & 1 & 3 & 1 & 3 & 1 & 20 & 50 \\
\hline R6 & 4 & 1 & 3 & 1 & 3 & 1 & 3 & 1 & 3 & 1 & 21 & 52.5 \\
\hline R7 & 4 & 1 & 3 & 1 & 3 & 1 & 4 & 1 & 3 & 1 & 22 & 55 \\
\hline R8 & 2 & 3 & 3 & 3 & 2 & 3 & 3 & 3 & 3 & 3 & 28 & 70 \\
\hline R9 & 4 & 1 & 3 & 4 & 3 & 3 & 3 & 1 & 4 & 3 & 29 & 72.5 \\
\hline R10 & 4 & 0 & 4 & 0 & 4 & 0 & 4 & 0 & 4 & 0 & 20 & 50 \\
\hline R11 & 3 & 2 & 3 & 2 & 3 & 2 & 3 & 2 & 3 & 2 & 25 & 62.5 \\
\hline$\ldots$ & $\ldots$ & $\ldots$ & $\ldots$ & $\ldots$ & $\ldots$ & $\ldots$ & $\ldots$ & $\ldots$ & $\ldots$ & $\ldots$ & $\ldots$ & $\ldots$ \\
\hline R101 & 3 & 3 & 3 & 4 & 4 & 4 & 3 & 4 & 4 & 4 & 36 & 90 \\
\hline Total Score & 248 & 263 & 328 & 309 & 317 & 265 & 328 & 265 & 338 & 275 & 2936 & 7340 \\
\hline & & & & Average SUS Score & & & & & 72,67 \\
\hline
\end{tabular}


To get the average SUS score from the system usability scale, it is necessary to add the values of questions number 1 to 10 of each respondent, then multiplied by 2.5 (Total score $\mathrm{x} 2.5$ ). After all of the respondents score have been calculated, then the total score of each respondent is added and divided by the total number of respondents. From the table above, it is found that the total score is 7340 , then that score will be divided by the total number of respondents (7340/101). Found the mean value of SUS in this research is 72,67.

\subsection{System usability scale assessment}

After getting the results of the questionnaire, researcher did the calculations according to the system usability scale method. And then found that the average SUS score in this research is 72,67. And then assess the SUS score using SUS score scale from Bangor. The following is an assessment of SUS according to Bangor

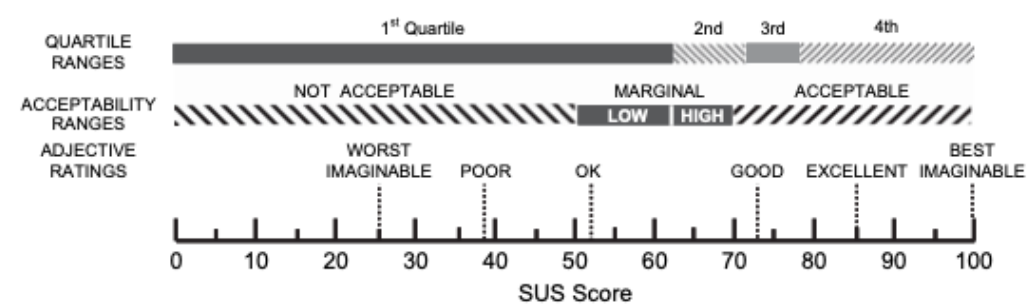

Fig. 3.13 SUS Score assesment(Bangor et al., 2008)

To find out the SUS value that falls into the acceptable category, Bangor argues that the system can be said to be feasible, if it has an average SUS score atleast 70 . Then for systems that can be categorized as good, have an average SUS score from the 70s to 80s. And for a system that falls into the very good category, has an average SUS score above 90 . And for systems that have an average SUS score below 70 can be considered as a system that should be put under surveillance for further development(Bangor et al., 2008). In this research, the average SUS score value obtained was 72.67. So that the SUS value from website Pijar Mahir is in the category of acceptable. Based on the result, can be concluded that this website can be used normally without any major problem.

\section{Conclusion}

Based on the evaluation of the Pijar Mahir's website research that has been done, the author can conclude:

- There is no previous research / publication on the Pijar Mahir's website, especially in the user experience. So it is expected that through this research it can be useful for both the Pijar Mahir's website development team, and as well as people who are willing to research the Pijar Mahir's website. And this research can be continued either by reusing this study or by using a different approach of research model to cover more finding in the usability aspect.

- After evaluating the Pijar Mahir's website, it can be concluded that this website has been in the acceptable category with a SUS score of 72.67. So this website is expected can be used for the all people without any major problems.

\section{References}

[1]. Alathas, H. (2018). Bagaimana Mengukur Kebergunaan Produk dengan System Usability Scale (SUS) Score. $\quad$ https://medium.com/kelasux/bagaimana-mengukur-kebergunaan-produk-dengan-systemusability-scale-sus-score-2d6843ca780a

[2]. Bangor, A., Kortum, P. T., \& Miller, J. T. (2008). An empirical evaluation of the system usability scale. International Journal of Human-Computer Interaction. https://doi.org/10.1080/10447310802205776

[3]. CNBC Indonesia. (2018). Tingkat Pengangguran RI Terendah Sejak Sebelum Krisis 1998. 
https://www.cnbcindonesia.com/news/20180507134348-4-13906/tingkat-pengangguran-ri-terendahsejak-sebelum-krisis-1998

[4]. Hasanah, A. (2016). Dampak Pengangguran Bagi Suatu Negara. https://www.kompasiana.com/awil/57fc2d2786afbd120922605a/dampak-pengangguran-bagi-suatunegara

[5]. International Organization for Standardization. (2010). ISO 9241-210: Ergonomics of human-system interaction - Human-centred design for interactive systems. In International Organization for Standardization.

[6]. Sugiyono. (2018). Pengertian Populasi dan Sampel Menurut Para Ahli. Journal of Chemical Information and Modeling.

[7]. Sukirno, S. (1994). Pengantar Ekonomi Makro Edisi Ketiga. Jakarta: Rajawali Pers. 